\title{
The Administrative and Technical Aspects in Baghdad and Cairo's House of Wisdom Libraries (a Comparative Analysis)
}

Adel M. Abdulaziz Algeriani* and Mawloud Mohadi

University Islam, Malaysia

\begin{abstract}
Muslim librarianship and penmanship were established due to the Qur'anic and Prophetic teachings. Some Muslim monarchs in the times Umayyads, Abbasids, Fatimids and others carried out the quest for learning and education and they considered it part of the faith, their utmost concern was accumulating books as well establishing libraries. This paper investigates the dawn of Muslim librarianship and its development as well as an overview of Baghdad and Cairo's Houses of Wisdom libraries. It also examines the administrative, managerial and technical aspects within the two chosen institutions as they had a remarkable set of administration and financial management. The current paper will be significant in the way it historically deals with the administrative and technical features of two of the most celebrated libraries in Muslim education. The paper follows a qualitative research founded on historical and descriptive approaches, through which the data was collected and interpreted objectively and accordingly.
\end{abstract}

Keywords: Muslim education; The house of wisdom; Baghdad; Cairo; The administrative and managerial aspect; The technical aspect

\section{Introduction}

The beginning of Muslim era dates from the time of the Prophet's hijrah along with his handful followers from Mecca to Medina in 622 A.D. The religion founded by Prophet Mohammed peace be upon him was not destined to become an insignificant sect or cult or peculiar to that specific isolated areas for after some years it has spread to different lands the names of which were probably not known to the Prophet peace be upon him and his followers. Islam did not remain simply a religion, instead the submission to Allah has become the core of a great civilization which united wide lands and peoples from different races, languages and cultures.

Despite the fact that ignorance was quite spread during the preIslamic era, Arabs seem to have been well acquainted with the art of writing. Ibn al-Nadim the famed author of Al-Fihrist, reported that Arabs of the Jahiliyyah era were well acquainted with "al-Khat al-Habashi", or the hand writing of Abyssinian as well as with the southern tribes of Saba and Himyar handwritings. The use of the above-mentioned materials continued to be in use during the times of Prophet Mohammed and onward, indeed the Qur'an has been recorded in papyrus, pals fibres bone tablets, hides, and parchment.

The Muslim education started as early as Prophet Mohammed received the early Qur'anic verses, later on, the Umayyads, the Abbasids and the other Muslim rulers contributed in rising the Muslim civilization to its heights which were never surpassed before until the age of European Renaissance. One of the very crucial institutions that carried out the mission of cultural and civilizational wakening and progress were the libraries. As established within the previous pages, the Umayyad and the Abbasid caliphs were the earliest patrons who dedicated their fortunes to further the foundation and development of the libraries. It is also worth mentioning that not only the Abbasids were head of the intellectual movement in Muslim civilization. Muslim rulers from other dynasties and regions from Spain to India were also committed to book collections and zealots of librarianship.

Public, private, caliphate, school, mosque and other kinds of Muslim libraries were not confined only in Baghdad, but as we have discussed, in a span of time libraries appeared in almost every corner of the Muslim civilization, they functioned as centres of the Islamic faith, culture, and society. The defragment of the Abbasid state surely caused some sort of weakness in the Muslim state central power; but people's cultural life never slowed down due to this political instability. On the contrary, they enjoyed a lot freedom in pursuing knowledge and scientific research throughout almost every Muslim land. As a result we found that the Umayyads in Spain, Abbasids in Baghdad, Samanids in Bukhara, Hamdanids of Aleppo, Buwayhids in Persia, Fatimid in Cairo and others, they all accumulated a huge collections of books and founded magnificent libraries.

Almost similar to any social or cultural institutions the Houses of Wisdom grew up constantly from small starts. Although there was a great enthusiasm in book collection and establishment of the Houses of wisdom, knowledge and information were not very abundant. It is thus unfortunate that Muslim historians Arab or otherwise, left no systematic studies of these cultural and educational institutions which prospered throughout the Muslim history. Consequently, in gathering the information for the comparative analysis of the two Houses of Wisdom in general and the Houses of wisdom of Cairo and Baghdad in particular, we had to depend on scattered information of Arabic and non-Arabic works that dealt with various themes such as Muslim religion, education, history, geography and other related literary works.

\section{A Historical Overview of Muslim Libraries and Development of the Houses of Wisdom}

There has been a general consent among historians that a variety of libraries have dispersed during the Islamic age which represented a twist of the cultural and intellectual movement in the Islamic world. The dawn of Islamic libraries was during the Umayyad dynasty and reached their peak in the times of the Abbasids and Fatimids then they

*Corresponding author: Adel M. Abdulaziz Algeriani, Coordinator of Islamic Heritage University Islam, Malaysia, Tel +603-8324 6666; E-mail: adel@uim.edu.my

Received July 25, 2018; Accepted August 01, 2018; Published August 07, 2018

Citation: Algeriani AMA, Mohadi M (2018) The Administrative and Technical Aspects in Baghdad and Cairo's House of Wisdom Libraries (a Comparative Analysis). Arts Social Sci J 9: 402. doi: 10.4172/2151-6200.1000402

Copyright: (c) 2018 Algeriani AMA, et al. This is an open-access article distributed under the terms of the Creative Commons Attribution License, which permits unrestricted use, distribution, and reproduction in any medium, provided the original author and source are credited. 
expanded to cover almost every soil on the Islamic state including Spain.

Subsequently after the time of Mohammed's Prophethood (pbuh) and after the expansion of the Muslim empire from Trans-Oxus to North Spain and southern part of France Starting with nothing, the Muslim Arabian Caliphate had flourished to become the ruling power of all world [1].

The Arabs have had no libraries or books except for very few clay records prior the time of Mohammed (pbuh). They were Bedouin people (nomads) living under tents and clay houses and traveling from area to another. They say that very few of them were able to read and write, however they had their own kind of culture or civilization for they had been able to study poetry, oratory, genealogy, primitive medicines and astrology [2-5]. The educated Arab community had their own meeting places to recite and contest in poetry. While there had been over twenty arenas for annual fairs during specific seasons.

The pre-Islamic Arabs are reported to have utilized various materials for the purpose of writing. Famously were the riq parchment, jareed or palm leaves, lukhaf, stone tablets and bone tablets produced from butchered camels and sheep. Even though the climate was not conductive to preserving the writing materials used in the era of preIslam in Arabia, many inscriptions have been found on stone and metal in recent times [6-8].

It is also believed that story writing as well as fiction was cultivated Mecca and other parts of the Arabian lands. Based on an authority on ancient poetry of the Arabs, Lyall maintained that much of the Jahiliyyah verse was written by the middle of the Fourth century, contrary to what is generally said. Therefore, the presence of a large vocabulary for different instruments of writing in the Arabic language of pre-Islam could be interpreted as a proof that the use of such writing materials and hand-writings styles were very well established.

The arrival of Islam had brought a variety of cultural, social and intellectual changes. Prophet Mohammed (pbuh) had always stressed on the pursuit of knowledge and convinced his followers to seek it and acquire it for every possible sources. In the first decades after the advent of Islam, Muslim Arabs had no libraries and their literacy did not boost overnight $[9,10]$. When the Muslims of the first generations started their opening campaigns out of their peninsula, they were confronted in these new places by a very distinguished educational and philosophical series by the Greeks and Persians mainly in Egypt, Iraq and Syria.

In the sixth century and during the reign of Noshirvan (531579), the revival of Persian literature and the introduction of Greek philosophy and science into Persia along with Christian and Syrian elements have marked the medieval Oriental libraries to begin. Here we notice the transmission of Greek philosophy and Greek science to the East by the Syrians who translated these thoughts into Syriac language in Antioch, Edessa schools.

After the Arab conquest of Persia, they became heirs to the Persian literature, Persian philosophy, Greek philosophy and sciences. This huge body of thought and knowledge was instantaneously assimilated through the Arabic language translation [11-15]. When the Arabs were safely settled in the new territories, they have absorbed the new knowledge and formed new libraries filled with Islamic, Persian and Greek philosophy and sciences.

After the Assassination of Ali the fourth caliph in 661 and the establishment of the Umayyad dynasty in Damascus, Islam's capital had shifted to an area which was dominantly Christian and famous of its Hellenistic heritage of the Greek philosophy and thought for centuries. When the Umayyad dynasty reign was established in Damascus Syria, it is clear that they have come to face to face with Greek civilization that would later have an impact on the development of life, thoughts of the Muslim people.

Libraries like Pergamum and the imperial collections of Constantine and his successors might have passed to the Muslims. A tradition often states that al-Ma'mūn sent a commission to Leo the Armenian to obtain some of the books the caliph desired for his library [16-20]. It has been even said that this caliph has demanded books among the terms of treaty he concluded with the Byzantine king. Hence it is possible for those who collected Greek, manuscripts for the early Abbasid caliphs could have seen these libraries.

When the Abbasids assured their political dominance, they drew their attention to pursuit arts and knowledge and nurtured them. Historians generally agree that the first enlightened caliph was alMansur who is reported to have initiated the translation into Arabic many Greek and Persian works. His patronage and caliphs after him brought fruit to book industry and made it flourish inside and outside Baghdad which will eventually become a centre of learning and research for centuries. The immediate caliphs and al-Mansūr himself gathered a huge number of books that when Harūn al-Rashìd (786-808 A.D.) took office as the fifth caliph, he deemed it obligatory to found a library specifically for those accumulated books.

The library which al- founded was popular as Bayt al-Hikmah or House of Wisdom. As the name could signify, this library served triple-edged purposes. Firstly, it was the place to contain the hugely accumulated book collections. Secondly, the House of wisdom carried on the translation movement that was very significant for al-Mansur and his immediate successors. Finally, Bayt al-Hikmah became an academy that gathered students and scholars for their experiments, research and intellectual contemplation.

The Fatimid caliphs were similar to the Abbasids in their interest for learning and literature. Thus, under the former patronage, the Muslim civilization reached one its highest intellectual and cultural levels. The Fatimids encouraged learning and founded schools, colleges, mosques and libraries. One of the most influential rulers of this dynasty was the caliph al-Hakim (996-1021 A.D.) who founded Dar al-Hikmah or "abode of wisdom" which housed some of the richest and varied book collections in Muslim lands. It served as an instrument for the advancement of Muslim thought and sciences in North Africa.

The Egyptian historian al-Maqrizī gave the best description of Dar al-Hikmah in Cairo in his book al-Khitat:

On the year 1004 A.D., the building known as Dar al-Hikmah was opened in Cairo. Seekers of knowledge took up their assets. Books were brought from book chests of the palaces where the Fatimid caliphs reside, and the public was permitted to enter. Anyone was free to copy the book he wished, and who ever wanted to read a certain book found in the library could so. Men of learning studied the Qur'an, astronomy, grammar, lexicography and medicine [2].

This institution therefore, became in a short time the centre of Muslim thought and a school of sciences and literature. Besides the donation al-Hakim offered, $\mathrm{He}$ also sent agents to various places to purchase books for this new library. The caliph rendered Adar alHikmah accessible not only to fellows of the academy and employees but it was open to the general public. Again al-Maqrizī highlights: “ $A l$ 
Hakim permitted admittance to everyone, without distinction of rank, who wished to read or consult any of the books" [2].

Dar al-Hikmah is sometimes confused with the library of caliph alAziz. This private library was established in the interior Fatimid palace in Cairo. The fact that the two libraries were geographically near seems to have risen the confusion. But the Egyptian historian al-Maqrizī who lived in the capital city and died in 1441, rendered it clear that the abode of wisdom or Dar al-Hikmah and "al-Khizana al-Dakhilayyah", or the internal library were two distinct entities and very different [2].

\section{The Administrative and Managerial Features in Baghdad and Cairo's Houses of Wisdom}

The aspect of the Houses if Wisdom adminstration is of a great importance that it deserves to be dealt with separately from the financial or technical aspects. It was actually a fact that there was no single or united administration for Buyut al-Hikmah as they were managed by different people of different intellectuality and thinking. This administration was not mere for librarianship but it was an educational element and a community related feature.

Even though there is but little knowledge on such aspect in the scattered information, one could draw some border line for the administrative picture of Buyut al-Hikmah. In both Baghdad and Cairo, the fundamental staff of these two libraries composed of first, a director or wakil who was in charge of the management pf non-professional aspects of the library; second, was the librarian known as al-Khazin who is the manager of the professional aspects of the library, third there was the custodian or superintendent (mushrif) who was an organizer of the work, controller of the library and director of both administrative and professional employees in the library, his job sometimes can be extended to invigilation to prevent exploitation or robberies $[3,21,22]$.

We learn from different sources that the employment in both Cairo and Baghdad House of Wisdom was not given to ordinary people or based on social status, but it was given to people of high intellectuality and considerable level of knowledge in different branches of sciences [23-26]. The staff of these libraries were men of sciences, judges, scholars, philosophers etc. some heavy weighted names worked in Muslim libraries such al-Khwarizmi father of algorithm, al-Gazāli (Hujjat al-Islam), Ibn Sīnā known as the second master, al-Farabī and many others. As far as the Houses of Wisdom management is concerned, one cannot help but to discuss some basic tenets in their administration including book collection, book preservation and shelving, book lending, employment of librarians.

\section{Collection of books}

In dealing with the administrative aspect, book collection is a backbone element in the both Cairo's and Baghdad's House of wisdom. Historians often agree that the Abbasids as well as the Fatimids were patrons of the scientific revolution that occurred in the Muslim civilization. To meet this demand of civilizational uprising.

Historians who studied Bayt al-Hikmah in Baghdad have a general consent that that al-Rashìd was a merciful and tolerant man in religious matters. To enrich the House of wisdom with valuable books al-Rashid corresponded with Byzantine king. Ibn Abi Usabiy'a claims that the encounter between al-Rashid and the Byzantium king resulted in gaining many valuable Greek works which later on were translated into the Arabic language by a Christian physician and translator Yuhanna Ibn Masawaih [4,27-30].
The early Abbasid Caliphs took the House of wisdom in Baghdad into another level through their considerable vision, intellect and wisdom, they dedicated themselves to collect works on sciences and philosophy from Greek, Indian and Persian origin. Their prolific diplomatic skills allowed them to get hold of Greek works from different geographical spots. According to Ibn al-Nadim, the new accumulated collections were very large and very valuable so the caliphs chose some of the elites to manage the new brought collection. When the book collections arrive to Baghdad, they were placed in the House of Wisdom where eventually got translated into Arabic, the language of scientific research of that time.

The Fatimids also collected huge book collections mainly by rulers, aristocrats, men of learning and book lovers. The Fatimid were interested to gather all types of books for their library. Despite the fact that their library was composed of a great collection, they never hesitated to get hold of new books and they sent special agents to different regions to accumulate authentic manuscripts. For instance, the caliph al-Hakim sent his agents to Syria, North Africa, Sicily and many other regions to bring him valuable books and manuscripts. It is also said that al-Aziz another Fatimid Caliph spent extravagantly to acquire new book globes and maps, the caliph spent fifteen thousand Dinars to purchase a 2250 years old antic globe which is believed to have been made by Ptolemy [4]

\section{Book preservation and organization}

The accumulation of book collections was just the first leap towards making them accessible to scholars and students. Like almost every Muslim library regardless to its kind, the Houses of wisdom seem to have embraced the compilation of books or book listing and cataloguing, to facilitate their usability to people. This step helped control both quality and quantity of resources.

Both Houses of Wisdom in Cairo and in Baghdad encouraged book listing and cataloguing sometimes they organized their collection according to the alphabetical order but sometimes they organized them regarding their branch of knowledge, for instance we heard that the Abbasid caliphs assigned some of the elite to preserve books according to their field of knowledge into a different and separate rooms [31-34]. A common feature for the catalogue is that they all have quite a detailed description of the manuscripts and books found in the library. This assignment was given to high qualified librarians whose first mission is to make inventory of the collection of the library.

In addition to their energetic effort to compile catalogues, the Houses of Wisdom seem to have cared for the arrangement of these book collections. The written accounts have shown that librarians and assistants were workers of perseverance to retrieve and return the book collection back and forth. Therefore it indicates that the libraries collections were perfectly organized. The Houses of wisdom as well as other Muslim libraries wood shelves were widely used, however it is worth nothing that the craftsmanship and the extent of carving and decoration may vary from library to another.

The Fatimid as well as the Abbasid Houses of wisdom shared many common features. They both had long side rooms and arched room, the number of rooms is unknown but al-Maqrizi estimated that the Fatimid House of wisdom was composed of more than forty rooms and each room contained a full collection of twenty thousand five hundred book. Indeed the Abbasid House of wisdom in Baghdad contained a higher number of rooms and a much greater number of book collections [2]. 
Imamuddin also described the rooms in the Houses of wisdom as huge in number and large in size, he also states that there were huge book shelves adjacent to the walls of the rooms where the book were kept. The book shelves contained locks that were opened to anyone who wanted to read or needed a book from them. Every room in the Houses of wisdom had its own reading and checking corner, and they were all accessible if someone needs to collect data. Some rooms were devoted to listening and learning music and other arts. In both libraries, some rooms were special for copyists, translators and book binders. They have used many chemical substances to preserve books and manuscripts. They also used leather and painting to bind the manuscripts and made them more attractive and long lasting [5].

\section{Book lending}

Regardless to the emphasis on book collection, organization and arrangement, The Houses of wisdom ultimate strength was their ability to cope with the needs of scholars and students particularly when book lending and borrowing are concerned. Book lending is one of the measure through which we evaluate the library's success or failure. Shafi pointed out that free access to books was offered in all public libraries, where many facilities were provided hardly surpassed even in modern libraries. He also states that the Houses of wisdom provided freedom of use and liberal loan of book, they also supplied free stationary and book copying. This statement cannot be applied on some private and mosque libraries where were some sort of restrictions [6].

Book lending indeed has a strong basis in the Muslim tradition, for many scholars emphasised on benefiting others through education and book lending. However the libraries including the Houses of Wisdom in Cairo and Baghdad were somewhat cautious in lending out the valuable books. Shalaby is related to have mentioned some of these regulations that bound the book lending system. Among the regulations that the borrower was required to observe were: a monetary deposits were paid if the books were to be carried out of the library, (Baghdad House of Wisdom did not impose such deposit). The borrower should be honest and trustworthy men, for books were lend to only reliable men, foreigners were allowed to attend the library and enjoy its full facilities, only native citizens were allowed to borrow the books [4].

On the personal level, the borrower was advised to take care of the books, and was prohibited to correct any possible mistakes in the books or manuscripts except if he/she brought it to the attention of the librarian. No notes were allowed by the borrower in the intentionally left blank pages, the borrower was also urged not to lend the book to a third party. In addition to that the book borrower had to return the books by the end of the lending time or upon the request of the librarian in charge. Any failure to fulfil some of the regulation would jeopardize future lending possibilities. In addition to these codes one must not forget that some donors may impose more restricting regulations on their waqf collections, for example some donors required the librarians to write down the names of borrowers and erase them upon the books return [4].

\section{Appointment of librarians}

The Houses of Wisdom were run by patrons of knowledge and learning as well as men of ability and perseverance who were appointed as librarians whether they were translators, managers, copyists, lecturers or other positions that are related to librarianship:

Muslim bibliophiles... chose men of unusual attainment as custodians of their libraries. In fact much of the splendid activity of Arabic libraries is probably due to the quality of men who were pleased to act as librarians. It speaks highly for the generosity of the patrons as well as for the really important work carried on these libraries that men of marked ability in various fields felt it worth their while to undertake the duties of custodian.

It is often a fact that the appointment of a librarian, differently known as Wakil, Nadir, Sahib, Khazin, Amin, mushrif etc., to run the libraries affairs was a popular phenomenon. Anwar al-Rifa'i reported that upon the establishment of Bayt al-Hikmah in Baghdad the Caliphs appointed a librarian to run its collections. Al-Ma'mūn for instance assigned Sahl Ibn Harūn who was a vizier, as a mushrif of the House of Wisdom, however when the library was extended both in size and content, the House of wisdom then was led by a variety of librarians like Abu Sahl al-Fadl, Yuhanna Ibn Masawaih, Ibn al-Batriq, Thābit Ibn Qurrah and many others.

As for the House of Wisdom in Cairo, a highly skilled and educated persons were given the chance to be in charge of the library. They were often appointed by the respective authorities $[35,36]$. As it was noted before that the librarians come of various positions including book binders, book collectors, engravers, copyists, translators, etc. their number was dependent on the size of the library and its collections. The Fatimid Caliph al-Aziz appointed Ya'qūb Ibn Killis as collector and organizer of the book collections and Abu al-Hassan Ali Ibn Mohammed al-Shabushti was appointed the chief librarian of Bayt al-Hikmah in Cairo. Al-Qiftī also relates that during the reign of alHakim Abu Kashim Ali Ibn Ahmed was appointed chief administrator of the House of wisdom.

\section{The Technical Feature in the Houses of Wisdom of Baghdad and Cairo}

As long as the technical aspect is concerned, there are many different facets for it, however we will be only discussing two major spheres of the Houses of Wisdom Technical feature namely cataloguing, book duplication and reading areas. It has been largely discussed that Muslim libraries were used by the publicly or privately by either students or scholars. The book collections were arranged systematically in accordance with their subject and branch of knowledge. Masāhif or Qur'anic copies were placed in special places. Similar to our modern library book arrangement, the House of Wisdom in both Cairo and Baghdad arranged their book collection in shelves that are divided into sections.

The book collection shelving was according to the subject, both tittle and name of the author were written in the back side of the book. Something very amazing was done to simplify the search for the written literature, the contents of every single section of a bookshelf were registered in a strip or paper and attached to the shelf from the outside. These strips were also sometimes used as an indication for unfinished books [7].

In order to facilitate the use of book collection by the libraries attendees, all materials were catalogued perhaps according to their subject or branch of knowledge [37,38]. For instance in Cairo's House of Wisdom, there existed a strip fastened in every room door of the library which indicates the book contents of that specific room. As for the Abbasid's House of wisdom, Ibn al-Nadim who usually refers to the materials he consulted in this library, he relates that al-Ma'mūn appointed a special scholar whose job was the cataloguing of book collections.

The cataloguing process was carried out according to the subject of the book collection itself. The Houses of Wisdom indeed contained 
many beautifully copied masāhif along with other works on Islamic topics such as tafsir, exegesis, theology, Hadiths or prophetic tradition, Fiqh or jurisprudence, etc. these were not obviously not the only subjects covered in these libraries, however they include large collection of scientific and social literary works. One cannot help but to mention few areas arranged in shelves at both Houses of wisdom, besides the previously mentioned Islamic subjects, cataloguing also included biographies, mysticism, history, philosophy, geography, political sciences, chemistry, astronomy, farming, astrology medicines and music.

One remarkable issue in discussing the technical aspect is the duplication of books. The Houses of wisdom's book collections were usually introduced in several copies. This allowed the readers to enjoy same work borrowing, and gave scholars the opportunity to detect any corruption within the different copies of the same work through referring to the original manuscript. The same duplication process was made in both Houses of Wisdom in Cairo and Baghdad. It is related that the House of Wisdom in Cairo had twenty manuscripts of the History of al-Tabari which were the reference for other copies duplication [8].

The two large libraries in Baghdad and Cairo were open to students and scholars regardless to their faith, background and social status. Anyone who had the ability to read and write had the opportunity to be admitted to the library. it is worth noting that poor students and needy scholars were provided with free ink, paper, pens food and other facilities [8].

In addition to the cataloguing and book duplication, the Houses of Wisdom provided their attendees with adequate facilities for writing and reading. We have found no clear evidence of the availability of tables and char, but what is evident is that these libraries set aside specific rooms for readers and others for copyists and translators. Managers of the Houses of wisdom dedicated some permanent funds for these rooms to light them and fit them with carpets, mats and seating materials [39-42].

Both Houses of Wisdom in Baghdad and Cairo are reported to have contained very spacious rooms for attendees to read and study. Bayt alHikmah in Cairo which is said to have contained forty rooms of books had also very spacious halls for readers to study in them. Judging by the greater amount of funds that the Abbasids dedicated to their library, there must have been more rooms for readers and more facilities in it compared to that of Cairo.

\section{Conclusion}

Public, private, caliphate, school, mosque and other kinds of Muslim libraries were not confined only in Baghdad, but as we have discussed, in a span of time libraries appeared in almost every corner of the Muslim civilization, they functioned as centres of the Islamic faith, culture, and society. The defragment of the Abbasid state surely caused some sort of weakness in the Muslim state central power; but people's cultural life never slowed down due to this political instability [43]. On the contrary, they enjoyed a lot freedom in pursuing knowledge and scientific research throughout almost every Muslim land. As a result we found that the Umayyads in Spain, Abbasids in Baghdad, Samanids in Bukhara, Hamdanids of Aleppo, Buwayhids in Persia, Fatimid in Cairo and others, they all accumulated a huge collections of books and founded magnificent libraries.

Almost similar to any social or cultural institutions the Houses of Wisdom grew up constantly from small starts. Although there was a great enthusiasm in book collection and establishment of the Houses of wisdom, knowledge and information were not very abundant. It is thus unfortunate that Muslim historians Arab or otherwise, left no systematic studies of these cultural and educational institutions which prospered throughout the Muslim history. Consequently, in gathering the information for the comparative analysis of the two Houses of Wisdom in general and the Houses of wisdom of Cairo and Baghdad in particular, we had to depend on scattered information of Arabic and non-Arabic works that dealt with various themes such as Muslim religion, education, history, geography and other related literary works.

As we explored before, the book collections were given as gifts and as pious bequests also known in the Muslim tradition as awqaf or hubus to The Houses of wisdom (Buyut al-Hikmah). Though different in size and value, book collections were all accessible in use by common people or scholars [44]. The Houses of Wisdom had some different managerial, administrative and even financial matters that were related to the era or place established at, or due to the wealth of the founding authorities. However it is evident that The Houses of Wisdom whether in Cairo, Baghdad, Bukhara, Marrakech or elsewhere, they altogether were an integral component of the Muslim cultural and educational life of those times.

Buyut al-Hikmah indeed, were not a mere storing houses for books, maps manuscripts and other items, and they were not entrusted to ignorant people of the society. Buyut al-Hikmah served as centres of intellectuality and learning, despite age, it assembled young and old men and women who were willing to study, teach and debate. In addition to that the librarians were cautiously selected from the elite of their time and according to their knowledge of books and other literary accomplishment, men like that were always eagerly sought and received by caliphs, viziers and especially scholars [45]. In addition, the Houses of Wisdom provided students and scholars with irresistible facilities like free ink, paper, food, accommodation, etc. their management was systematic, wise and effective which as we viewed had a very positive impact on the social and intellectual life of in the Muslim civilization.

Buyut al-Hikmah and other Muslim libraries had a great impact on the development of European libraries, their fame most probably inspired Louis XI of France to imitate these institutions and $\mathrm{He}$ founded a library in Paris which contained huge number of book collection and became a public library. The Houses of Wisdom were the centres in which optics, physics, philosophy medicine and others were being translated, explained and expanded. Comprehensive summaries of Greek, Persian, Syrian and Byzantine works were brought into light. The late era of the Middle Ages had to understand and embrace the new Greek-Arabic culture and sciences. The legacy of some of the great civilizations including Greek, Byzantine, Persian and Arabic were all inherited and utilized and made the European Renaissance possible [8]

In the middle of the thirteenth century the Muslim civilization was agonizing due to the onslaught of the Mongol invasion whose influence was very disastrous on the Muslim heritage. When they burned almost every library they came across and threw its books and intellectual treasures into the rivers. Before the end of the thirteenth century, the most valuable books, manuscripts, maps globes and other materials that made up the main components of the Houses of Wisdom and other similar Muslim libraries, were in European hands in a form of translation or in their original form. Some decades later, during the expulsion of the moors from Spain thousands of books and materials were burned [46-49]. The onslaught against Muslim libraries by foreign invasions was carried continuously in the Muslim lands from Baghdad to Egypt and from Spain to Morocco. 
Citation: Algeriani AMA, Mohadi M (2018) The Administrative and Technical Aspects in Baghdad and Cairo's House of Wisdom Libraries (a Comparative Analysis). Arts Social Sci J 9: 402. doi: 10.4172/2151-6200.1000402

Page 6 of 6

\section{References}

1. Hitti Philip K (1937) History of the Arabs London: MacMillan.

2. Ali AMAI (1959) Al-Mawaiz wa al-l'tibar fi Dhikr al-Khitat wa al-Athar Beirut: Dar al-Urfan.

3. Adam M (1937) The Renaissance of Islam Tranlated by Khuda Bukhsh and DS Margolioth London: Luzac.

4. Ahmed S (1954) History of Muslim Education Beirut: Dar al-Kashaaf.

5. Imamuddin SM (1983) Arabic Writing and Arab Libraries London: Ta-Ha Publishers.

6. Mohammed S (1961) Libraries and Learning in the Muslim World Pakistan Library Review.

7. Stellhorn MR (1935) Background of the History of Muslim Libraries The American Journal of Semitic Languages and Literatures.

8. Olga $P$ (1929) The Libraries of the Arabs during the time of the Abbasids Islamic Culture.

9. Abd al-Badi'i L (1969) Al-Islam fi Ispanya Cairo: Maktabat al-Nahda.

10. Abd al-Jabbar A (1959) Al-Maktabat fi Qalb Al-Jazeera al-Arabiyaah Al-Adib

11. Abd al-Wahab H (1946) Tarikh al-Masajid al-Arabiyaah Cairo: Dar al-Kutub.

12. Al-Wahab A, Husni H (1963) Bayt al-Hikmah al-Tunisi Majjalat majma al-Lugha al-Arabiyaah Cairo.

13. Abd al-Wahab Hassan Husni (1964) Waraqat an al-Hadhara al-Arabiyyah bi Ifriqyah al-Tunusiyaah Tunis: Maktabat al-Manar.

14. Al-Deen AM (1968) Muslim Education and the Scholars Social Status Up to the 5th century Muslim Era (11th century Christian era) Zurich: Verlag Der Islam.

15. Al-Duyuji S (1972) Bayt al-Hikmah Cairo: Dar al-Kutub.

16. Al-Jaburi AA (1969) Maktabat al-awqaf al-Ammam Tarikhuha wa Nawadir Makhtutatiha Baghdad: Matbbat al-Maarif.

17. Al-Sayyid AA, Al-Fadl AA (1978) Makka fi Asr Maqabla al-Islam Riyadh: Dar al-Hilal.

18. Kurkis A (1948) Khazain al-Kutub al-Qadima fi al-Iraq Baghdad: Matbaat alMa'arif.

19. Mohammed B (1897) Madinat al-Qyrawan al-Muqtataf

20. Khuda BS (1902) The Ninteenth Century and After: The Islamic Libraries.

21. Khuda BS (1930) The Renaissance of Islam: the Savant Islamic culture.

22. Carter Rhomas (1931) The Invention of Printing in China and its Spread Westward New York: Columbia University.

23. Shawqi D (1973) Tarikh al-Adab al-Arabi 3vols Cairo: Dar al-Ma'arif Bi Misr.

24. Bayard D (1962) Muslim Education in Medieval Times Washington: Middle East Institute.
25. Anne D (1913) Spanish Islam a History of the Muslims in Spain London: Chatto and Windus.

26. Yusuf E (1967) Les bibliotheques Arabes Publiques et semi-Publiques en Mesopotamie en Syrie et en Egypte au Moyen Age Damascus: Institut Francais.

27. Encyclopaedia of Islam (1938) ed Sv "Masdjid" by Pederson

28. Al-Aadid A (1959) Khizanat al-Qarawiyyin wa Nawadiruha Majallat Mahd alMakhtutat al-Arabiyyah.

29. Mahir HM (1981) Al-Maktabat fi al-Islam nashatuha wa tatawuruha wa masa'iruha Beirut: Muassassat al-Rissala.

30. Ibrahim HH (1964) Tarikh al-Dawla al-Fatimiyyah Cairo: Maktabat al-Nahda.

31. Abi Usabiya I (1965) Uyun al-Anba fi Tabaqat al-Atibbaa Beirut: Dar Maktabat al-Hayat.

32. Al-furat I (1936) Tarikh Ibn al-Furat Beirut: al-Matba'a al-Amricaniyyah.

33. Al-Hafidh IA (1990) Al-Takmilah li Kitab al-Silah Beirut: Dar al-Fikr.

34. Lisan al-Din IA (1968) Nufadat al-Jarab Fi Ulalat al-Ightirab Cairo: Dar al-Katib al-Arabi.

35. Ibn Ishaq MI (1984) Kitab al-Fihrist Beirut: Dar al-Ma'rifa.

36. Al-Latif IA (1962) Dirasat fi al-Kutub wa Maktabat al-Islamiyah Cairo: Dar alShab.

37. Imamuddin SM (1983) Some Leading Muslim Libraries of the World Dhaka: Islamic Foundation Bangladesh.

38. Inyatullah Sh (1938) Bibliophilism in Medieval Islam Cairo: Islamic Culture.

39. Allah KA (1908) Al-Nubugh Al-Maghribi fi al-Adab al-Arabi.

40. Hajī K (1982) Kashf al-Dhunun Beirut: Dar al-Fikr.

41. Mohammed KA (1929) Al-Kutub wa al-Makatib fi al-Sham Al-Muqtataf.

42. Stellhorn MR (1939) Arabic books and Libraries in the Umayyad Period the American Journal of Semitic Languages and Literatures.

43. Stellhorn MR (1932) Four Great Libraries of Medieval Baghdad The Library Quarterly.

44. Najī M (1969) Asalat al-Hadara al-Arabiyyah Baghdad: Matbaat al-Tamaddun.

45. Thomson James W (1923) The Medieval Library New York Hafner Publishing Co.

46. Tibawī AL (1998) Muslim Education in the Golden Age of the Caliphate Islamic Culture.

47. Yaqūt al-Hamawī (1866) Mu'jam al-Buldan Leipzig: FA Brockhaus.

48. Jurji Z (1965) Al-Arab Qabl al-Islam Cairo: al-Matbaat al-Amiriyyah.

49. Jurji Z (1957) Tarikh Adab al-Lugha al-Arabiyaah Cairo: Dar al-Hilal. 